\title{
Humanization of the Russian housing model in the postmodern space
}

\author{
Leyla Leonova ${ }^{1 \mathrm{a}}$, Elena Alpatova ${ }^{1}$, Stefan Kowalczyk ${ }^{2}$, and Tatyana Rutkauskas ${ }^{1}$ \\ ${ }^{1}$ Ural State University, 620002, Yekaterinburg, Russia \\ 2 President Livia Projects International Inc., Calgary, Alberta, Canada
}

\begin{abstract}
The article analyzes the existing approaches of management in the sphere of housing and communal service in Russia (HCS). They have not improved the quality of life and have not ensured sustainable reproduction of the human capital. According to the authors, the implementation in practice of Anglo-Saxon governance model in Russia has not proved the historical context of the country's development. A comparative analysis was conducted of housing sphere of Russia and the European Union. It is recommended to use the Scandinavian management model as a more acceptable for the Russian conditions.
\end{abstract}

Signs of global post-industrial era have undergone changes: digital technologies and social experiments have become symbols of modernity. Technological advances are taking place in the world. However, a significant part of the population is not provided by basic housing infrastructure. They live in bad conditions. They exposed to detrimental environmental factors. In the past two decades the social inequality has deepened, the "unauthorized" settlement of immigrants in large cities has appeared. EU countries also have fully felt the "tsunami" of refugees and migrants in 2014-2015.

The growth of destructive socio-political trends devalues people's desire for a "better" life.

Economic, political and environmental turbulence in system leads to the realization of "fragility" and doom the future, deprive each person of faith in a positive future world order. Prigogine believed that «the world evolving from order to chaos» [1]. Chaos is not the final state of the universe. The new structures are born from it. However, the transition states themselves cause the people to feel fear and rejection.

In the context of the cultural space of postmodernity the apprehension of frightening multivariance progress has come. It brings not only technological advances, but also wars, destruction and alienation. It is difficult to see a reference point of civilization to the man of post-industrial society.

On the other hand, postmodernity has brought the idea of a permanent social change to the world, change incentives for the formation of the inner freedom of the individual. Postmodern, released from Europe, covered all socio-cultural and economic models of the reflecting world. The dominant postmodern trend has reduced the dependence of the individual from the institutions of politics and economics.

\footnotetext{
a Corresponding author: 1el.leo@mail.ru
} 
The life of modern cities is a typical example of postmodern culture with economic imbalances and social segregation: "Intelligent" high-rise buildings of infill development literally "are pushed" on land plots between dilapidated buildings today, digital and physical world grow into each other, national, demographic composition of people has uncontrolled changes. There are the questions arise about the "protection" of life: settlements are controlled by electronic systems, but they also reveal their vulnerability [2].

Civilization general models of urban management develop In the context of postmodern. We have acquired new technologies, methods and mechanisms of interaction, for a whole century, however we have lost the value targets.

An excursion into the history of the issue allows us to analyze the changes of management in housing and communal services (HCS) since the beginning of the XX century to the present and pay attention to aspects of modern management which require immediate changes in management approaches.

Basic management methodology in housing and communal sphere in Russia had been included in the publication of L.A. Velikhov, "Fundamentals of Municipal Economy" in 1928 [3].

Of course, a person is not regarded in the system as the central link, but he is a means, an "element" of the socialist city. A secondary role was assigned for comfortable housing, infrastructure and services sector.

However, the ideology of the urban economy had a social entity. This ideology has been adopted as the basis in the Soviet period of management. Housing and communal sphere has been recognized as acute social, necessary for the reproduction of the population. The start of mass housing construction in the USSR began in 1954. For fifteen years (to 1969), 1.469 billion square meters of housing was built [4]. Due to the famous "Khrushchev" people moved from dugouts, communal houses to separate apartments. At the same time, all the engineering support of infrastructure systems in the houses has been established. This infrastructure has remained viable until the '90s.

In the so-called "of reform" period (since 1991), HCS was based on the life-support facilities of the Soviet period. They quickly grow old. It required large financial costs of subsidizing sphere (major repairs of residential buildings, urban relaying of utilities, construction of pumping stations, sewage treatment plants, waste recycling). However, the country's attention was focused on the interesting political events of "perestroika".

Since the adoption of the law "On privatization of housing stock in the RSFSR" in 1991 [5] and transition of HCS to a break-even operating mode marked departure from the elements of the social nature of the system, despite the fact that the poor families needed the targeted social protection. Often, because of bureaucratic obstacles the assistance was a great problem. The system of subsidies for socially disadvantaged groups of population exists since today.

Russian HCS is a quality of life indicator which shows the critical depreciation of fixed assets, in 2014 it was about $43-52 \%$. For example, the wear of water supply and sanitation systems in some Russian cities reaches 80-90\% [6]. According to experts, the wear of equipment more than $50 \%$ exceeds the threshold economic security indicators in the country in 2 times. Table 1 shows the wear of the basic structure of HCS funds [6].

Table 1. Depreciation of fixed assets in the construction, production and distribution of water, gas and electricity, \%

\begin{tabular}{|c|c|c|c|c|c|c|c|}
\hline Type of economic activity & $\mathbf{2 0 0 8}$ & $\mathbf{2 0 0 9}$ & $\mathbf{2 0 1 0}$ & $\mathbf{2 0 1 1}$ & $\mathbf{2 0 1 2}$ & $\mathbf{2 0 1 3}$ & $\mathbf{2 0 1 4}$ \\
\hline All fixed assets & 43,5 & 45,2 & 45,3 & 45,3 & 47,1 & 47,9 & 48,6 \\
\hline $\begin{array}{c}\text { Manufacture and distribution of electricity, } \\
\text { gas and water }\end{array}$ & 55,6 & 52,2 & 51,2 & 50,7 & 51,1 & 51,2 & 51,2 \\
\hline Building & 42,3 & 44,6 & 45,5 & 46,9 & 48,3 & 49,4 & 47,3 \\
\hline
\end{tabular}




\begin{tabular}{|l|l|l|l|l|l|l|l|}
\hline Other community and social services & 42,9 & 39,8 & 40,7 & 42,5 & 44,5 & 45,1 & 43,4 \\
\hline
\end{tabular}

Poor infrastructure, high level of corruption and growing social inequality among the population are the results of the conservative modernization during the Soviet and postSoviet period. More than 4.5 million Russian citizens live in dilapidated and emergency housing. $40 \%$ of buildings (homes) need major repairing [7].

More than ten years ago monography "Why Russia is not America" (A. Parshev) [8] and a series of articles S. Kara-Murza "Problems in the Russian house" [9] were published. Later the "King-cold, or why Russia freezes" (S. Kara-Murza) was published too. [10]. The authors of the articles carry out the idea of the distinctive features of the housing and communal sector in Russia.

Only poor population of this country is not able to pay for all housing difficulties. This point of view is also relevant today.

We believe that in the second decade of the twenty-first century a deep change in management conception of housing and communal services in Russia is necessary. The traditional features of the national economy also must be taken into account. What is the base of this position? Firstly, housing and communal sphere in Russia is not only the production of market services. This area is strongly connected with the political system of the state and is always played as a "trump card" during the every election political campaign.

Secondly, there are the whole monopoly in production and delivery of life-support resources and the absence of a healthy competition in HCS in Russia. In the sphere, where monopoly firms dictate the rules, there is not any basis for competition and the formation of the healthy market relations. And this is, in turn, leads to a constant increase in tariffs.

Thirdly, for the formation of the healthy market relations in the housing and communal sector a system of cooperation between all market counterparties is necessary. This interaction based on eleven process organization principles. They are presented in Table 2.

Table 2. Basic principles of market relations

in Russia's sphere of housing and communal services

\begin{tabular}{|c|c|c|}
\hline $\begin{array}{c}\text { The principle } \\
\text { of a market economy }\end{array}$ & Summary principle & $\begin{array}{c}\begin{array}{c}\text { Features housing and communal } \\
\text { sector }\end{array} \\
\end{array}$ \\
\hline Freedom of choice & $\begin{array}{l}\text { The right market subject to } \\
\text { purchase and use their own } \\
\text { resources }\end{array}$ & $\begin{array}{c}\text { Companies - suppliers of resources - } \\
\text { monopolists. } \\
\text { The customer has no right to select } \\
\text { either a resource or a supplier }\end{array}$ \\
\hline Competition & $\begin{array}{l}\text { Availability filled } \\
\text { independently functioning } \\
\text { market sellers and buyers } \\
\text { of products and services }\end{array}$ & $\begin{array}{c}\text { Sellers of resources are mainly } \\
\text { monopolists. } \\
\text { Consumers do not have the right to } \\
\text { choose a supplier } \\
\text { The centralization of systems } \\
\text { engineering house life support }\end{array}$ \\
\hline Market segmentation & $\begin{array}{l}\text { Market Share in the consumer } \\
\text { groups according to income } \\
\text { Identifying market segments } \\
\text { that are "served" by } \\
\text { competitors }\end{array}$ & $\begin{array}{c}\text { There is no segmentation in apartment } \\
\text { buildings } \\
\text { Consumers with high incomes } \\
\text { purchase apartments of larger area }\end{array}$ \\
\hline Targeting & $\begin{array}{l}\text { The poor families need } \\
\text { the targeted social protection. }\end{array}$ & $\begin{array}{l}\text { Rigid frame subsidies (Payment } \\
\text { of housing services should be more } \\
\text { than } 22 \% \text { of total family income). } \\
\text { Bureaucracy of the subsidy process }\end{array}$ \\
\hline Paid & $\begin{array}{l}\text { The obligation of timely and } \\
\text { fully payment for the supplied } \\
\text { resources and rendered }\end{array}$ & $\begin{array}{c}\text { A large number of non-payers } \\
\text { because of low incomes and inflated } \\
\text { prices }\end{array}$ \\
\hline
\end{tabular}




\begin{tabular}{|c|c|c|}
\hline & services & \\
\hline Free market pricing & $\begin{array}{l}\text { Prices are formed on the basis } \\
\text { of market conditions }\end{array}$ & $\begin{array}{l}\text { Regulation of prices and tariffs by } \\
\text { regional energy commissions } \\
\text { Government regulation of limited } \\
\text { indices of prices and tariffs increase. } \\
\text { Management companies have } \\
\text { the right to adjust the prices and } \\
\text { tariffs for the provision of certain } \\
\text { types of works and services }\end{array}$ \\
\hline Contractual relationship & $\begin{array}{l}\text { Market entities enter into } \\
\text { contracts for the provision } \\
\text { of utility services } \\
\text { There is a consumer } \\
\text { protection }\end{array}$ & $\begin{array}{l}\text { The owners of apartment buildings } \\
\text { have neither the right nor the ability } \\
\text { to enter into separate contracts for } \\
\text { the supply of resources. } \\
\text { Consumers are not protected from } \\
\text { the low quality services }\end{array}$ \\
\hline Government regulation & $\begin{array}{c}\text { Enforcement of existing } \\
\text { legislation by market } \\
\text { participants }\end{array}$ & $\begin{array}{c}\text { Inadequate of housing law and } \\
\text { legislation in the housing and } \\
\text { communal sphere }\end{array}$ \\
\hline $\begin{array}{c}\text { Formation of different } \\
\text { standards of housing } \\
\text { preferences }\end{array}$ & $\begin{array}{l}\text { Consumer preferences } \\
\text { opportunities for choice } \\
\text { of place of residence }\end{array}$ & $\begin{array}{c}\text { New and modern apartments are } \\
\text { about } 25 \% \text { of the housing. } \\
\text { Low income of } 70 \% \text { of the population } \\
\text { does not allow them to buy it }\end{array}$ \\
\hline Consumer priority & $\begin{array}{c}\text { The responsibility } \\
\text { of manufacturers and retailers } \\
\text { to consumers }\end{array}$ & $\begin{array}{l}\text { The consumer have the risk } \\
\text { of receiving low quality services }\end{array}$ \\
\hline $\begin{array}{l}\text { Interchangeability } \\
\text { of works (services) }\end{array}$ & $\begin{array}{l}\text { The consumer has the right to } \\
\text { replace inappropriate services }\end{array}$ & $\begin{array}{l}\text { This principle is impossible because } \\
\text { of centralizing infrastructure of life } \\
\text { support systems }\end{array}$ \\
\hline
\end{tabular}

In this article we compared the main market interaction principles and features of housing and communal sector and came to the conclusion that all of them do not promote effective governance in market relations. And it means that we could not blindly adopt market mechanisms and principals in the field of non-market relations. Besides, we can see a long influence of persistent negative factors to Russian economy.

Could the urban metabolism system keep the maintain stability under the negative influence factors? What management model will be suitable in the structure of nonstationary economic heritage processes? To answer these questions, the authors appealed to the international experience of housing and communal management. EU development strategy up to 2020: the reduction of the number of people at risk of poverty or social exclusion is the exhibitor of humanitarian progress in Europe. The poorest segment of population was identified by comparing the range of incomes and living conditions of the population [11]. This index is composed from the analysis of three indicators: the degree of poverty and deprivation and the number of people who have problems with job.

To sum up, the housing and communal sphere is socially oriented in all European countries. State authorities and governments kept under control HCS in all EU countries. Municipalities regulate the work of private enterprises in HCS and defend the rights of citizens. Municipalities guarantee a high quality of services. Sweden, Finland, Germany, Poland, England: the municipal management is a business in the form of management companies. Along with them the owners of apartments control housing maintenance. They come together into the non-profit consumer organizations. 
Associations of tenants and homeowners provide the working of the apartment complex. They dispose of financial resources and buy necessary services. The process of their activity is similar to the work of functioning of HOA (homeowners) in Russia.

On one hand, we can see the tight control from the public and the state organizations. On the other hand - there is the formation of a society clear position in the communal conflicts relations. This protects the residents from fraud and corruption.

The studying of positive foreign experience in apartment management has a considerable interest for Russians, because about $85 \%$ of them are living in apartment buildings. Table 3 shows features of apartment management models in EU (compiled by the authors).

Table 3. Features of apartment (housing) management models in EU countries (compiled by the authors)

\begin{tabular}{|c|c|c|}
\hline Country & Features of management model in apartment houses & Result \\
\hline Sweden & $\begin{array}{c}\text { An extensive network of housing unions and associations } \\
\text { promotes the rights of tenants and owners; } \\
\text { have the political authority } \\
\text { The work of the housing court } \\
\text { Differ payment service models: } \\
\text { - "discount model" - the selection and payment of actual } \\
\text { - "Deprices. } \\
\text { - } \\
\text { treatment of the subject property }\end{array}$ & $\begin{array}{l}\text { Ensuring clarity in } \\
\text { the activities } \\
\text { of control structures } \\
\text { and rates, } \\
\text { detection and } \\
\text { suppression } \\
\text { of corruption }\end{array}$ \\
\hline Finland & $\begin{array}{c}\text { Form of housing management - Management companies } \\
70 \% \text { are controlled by Management companies, } 30 \%- \\
\text { Council House Management companies make operational } \\
\text { control in accordance with the contract } \\
\text { The contract is a list of services, prices and conditions } \\
\text { Management company selects the operating organizations to } \\
\text { provide communal services } \\
\text { Operating organizations choose a method of providing } \\
\text { services: 1) independently 2) enter into contracts with } \\
\text { specialized companies (repair and construction, landscaping, } \\
\text { protection, waste recycling). The operator make annual report } \\
\text { on costs and incomes. } \\
\text { In the big cities of engineering support systems are in } \\
\text { municipal ownership. } \\
\text { Heating and water supplying systems are centralized. } \\
\text { Power plants may be in privately owner }\end{array}$ & $\begin{array}{c}\text { Minimization } \\
\text { of costs and } \\
\text { the application } \\
\text { of advanced } \\
\text { technologies (For } \\
\text { example, } \\
\text { the presence of oil } \\
\text { reserve stations } \\
\text { during low } \\
\text { temperature }\left(-30^{\circ} \mathrm{C}\right) \text {, } \\
\text { using of waste heat } \\
\text { homes) }\end{array}$ \\
\hline Germany & $\begin{array}{l}\text { Apartment house is managed independently The amount } \\
\text { of payment is determined by the general meeting. } \\
\text { Housemasters make cleaning. } \\
\text { Each owner of the apartment enters into a contract with their } \\
\text { own resources, supplier - water, electricity, gas. } \\
\text { Individual heating, due to boiler }\end{array}$ & $\begin{array}{l}\text { Full independence } \\
\text { of the residents, cost } \\
\text { minimization }\end{array}$ \\
\hline England & $\begin{array}{l}\text { The existence of private companies - suppliers of resources. } \\
\text { Each resident chooses resource provider, if it is necessary, can } \\
\text { change them, but not more than once a week }\end{array}$ & $\begin{array}{l}\text { Independent search } \\
\text { vendor minimizes } \\
\text { resource rent }\end{array}$ \\
\hline Poland & $\begin{array}{l}\text { Joint-stock company with } 100 \% \text {-ing state (municipal) capital. } \\
\text { All kinds of public services combined into a single state- } \\
\text { owned company. } \\
\text { She manages the finances, production resources and monitors } \\
\text { activities. } \\
\text { Resource Companies may have a different form of property }\end{array}$ & $\begin{array}{l}\text { Providing quality } \\
\text { services. Ensuring } \\
\text { the reliability } \\
\text { of housing and } \\
\text { communal services }\end{array}$ \\
\hline
\end{tabular}


The apartment buildings management forms abroad are very different: from the conclusion of individual or collective contracts with inhabitants of an apartment house with different resource providers as in England and Germany to the total municipal capital management in Poland.

But in spite of the management forms the main feature is to minimize the cost of consumers. And as a result we can see the rent reduction, clarity and transparency of costs and funding in HCS. This makes virtually impossible the existence of corruption.

HCS is very important in Scandinavia countries. Tenants' Association has a significant influence on public policy. In Finland, for example, as well as in Russia, there is a central heating and water supplying systems.

We have analyzed the work of the urban and municipal services of the above mentioned countries and selected the basic management models:

- "Anglo-Saxon" - provides total autonomy management to every inhabitant. "Scandinavian" - complete control of governments. Vital public services and resources such as heating and water supplying are centrally delivered. There is the "double" law protection of consumers. Residents are protected by the court and the government.

- "German" is individual management of each apartment house. Municipals control the autonomous engineering supplying systems.

In the Russian HCS sequentially implanted Anglo-Saxon governance model. However, the market management model does not show its effectiveness in the modern Russian conditions. The real market in Russia is impossible because of its historical heritage. The fact is a natural monopoly of the main suppliers of vital resources, such as gas, electricity, heat.

Russian HCS is not only an economic problem. This is an important political aspect of Russia's life, and is an extremely important social factor not only because of consumer behavior, but also the factor of surviving and reproduction of the human capital in harsh Russian cold climate.

For example, $85 \%$ of the population has a monthly income per person about one-two living wages In Russia. According to the Federal Law "On Living Wage" [12] the average per capita income does not exceed 8500 rubles. The monthly fee apartment for a family of three people is about 7000 rubles.

The government should regulate prices because prices are rising by $8 \%$ a year. But it must also to create an effective legal and legislative basis in the housing and communal sphere.

The rate of growth of tariffs and costs are quite different from those in the EU. For example, from 2001 to 2009, the prices increased by 6 times in Russia. Meanwhile the inflation rate in Russia was lower and prices for HCS in the European countries increased no more than 50\% [13]. Table 4 shows the calculated data of significant increase trend of tariffs for HCS from 2001 to 2010 in terms of average oil price of $\$ 54.83$ per barrel as the main source of livelihood in Russia [14]

Table 4. Increase of tariffs for HCS in 2009 in real terms,

$\%$ from the $2001[15]$

\begin{tabular}{|c|c|c|c|c|c|c|}
\hline Services & Russia & EU & Germany & Poland & Finland & Great Britain \\
\hline HCS and fuel & 144,5 & 12,0 & 5,5 & 19,2 & 15,7 & 25,2 \\
\hline Rent & - & $-0,7$ & $-4,4$ & 14,7 & $10,6$. & 3,1 \\
\hline $\begin{array}{c}\text { The content } \\
\text { of the housing }\end{array}$ & 150,4 & & 6,3 & 5,2 & 0,8 & 8,6 \\
\hline Water supplying & 199,2 & & $-1,2$ & 39,3 & 14,9 & 31,8 \\
\hline Electricity & 62,7 & & 32,0 & 23,1 & 33,2 & 54,6 \\
\hline Gas & 98,6 & & 16,6 & 45,8 & - & 108,4 \\
\hline
\end{tabular}




\begin{tabular}{|l|c|c|c|c|c|c|}
\hline Heat supplying & 172,5 & & 22,9 & 9,3 & 45,3 & - \\
\hline
\end{tabular}

In the 90 years of the twentieth century, Russia was in a situation of duality contrasting models: socialist and market. According to the authors, unconditional transition to market concepts without taking into account national features and specificities was originally risky for the main areas of the economy, including HCS sector.

Postmodern as a system of flexible features, offers us "intermediate" model for countries with ethnic, cultural and historical characteristics. And these models are successfully operating. Models balance between the economic freedom principle and social regulation.

Having the positive examples of the European experience, Russian housing reformers installation to the "Anglo-Saxon" management model could not be considered as the only appropriate in Russia. It is based on the total privatization of vital important infrastructure and the total market economy transition.

Because of its cold climate and mentality of the population, as well as limited resources and the level of living of its poor population, the most acceptable for Russia could be the "Scandinavian model" as a model of "intermediate" type.

Taking into account the historical monopolism and centralization in HCS, as well as the current state of the economy it is necessary to use systematic public and government monitoring of the HCS management in Russia. It is necessary to take into account the historically established monopolism, centralization of essential housing and communal services, and the current state of the economy in Russia. Public authorities, government and society should control the management of housing and communal services.

\section{References}

1. I. Prigogine, I. Stengers, Order out of chaos. Man's new dialogue with nature (London 1984)

2. G. O'Tuathail, The Postmodern Geopolitical Condition: States, Statecraft, and Security at the Millennium Annals of the Association of American Geographers, 90-1 (2000)

3. L.A. Velikhov, Fundamentals of urban management (1996)

4. History of housing and communal services in Russia, http://www.muromraion.ru/node/3652

5. Federal Law of 04.07.1991 No. 1541-1 (ed. of 16.10.2012) "On privatization of housing stock in the Russian Federation", http://www.consultant.ru

6. B. Livshits, System analysis of market reform unsteady economy of Russia: 1992-2013 (2013)

7. International experience in communal sphere, http://dgkh.mos.ru/internationalexperience-of-housing

8. A. Parshev, Why Russia is not America? (2006)

9. S. Kara-Murza, S. Telegin, Problems in the Russian house (2004)

10. S. Kara-Murza, S. Telegin, King-cold freezes or why Russia (2006)

11. Household composition statistics, http://ec.europa.eu/eurostat/statisticsexplained/index.php/Household_composition_statistics

12. Federal Law of 24.10 .1997 No. 134 "On Living Wage", http://www.garant.ru

13. Europe in figures - Eurostat yearbook 2012: Living conditions and social protection Eurostat (2013)

14. The dynamics of oil prices since 1990, http:/tass.ru/economika/1572991

15. O.N. Kraeva, Scientific electronic journal, http://uecs.ru/uecs49-492013/item/19412013-01-21-11-01-42 